\title{
CARBIDE MORPHOLOGY AND FERRITE GRAIN SIZE AFTER ACCELERATED CARBIDE SPHEROIDISATION AND REFINEMENT (ASR) OF C45 STEEL
}

\author{
MORFOLOGIJA KARBIDOV IN VELIKOST FERITNIH ZRN PO \\ POSPEŠENI SFEROIDIZACIJI IN RAFINACIJI (ASR) JEKLA C45
}

\author{
Jaromir Dlouhy, Daniela Hauserova, Zbysek Novy \\ COMTES FHT, Prumyslova 995, 33441 Dobrany, Czech Republic \\ jdlouhy@comtesfht.cz \\ Prejem rokopisa - received: 2013-11-04; sprejem za objavo - accepted for publication: 2014-09-08
}

doi:10.17222/mit.2013.270

\begin{abstract}
The pearlite spheroidisation and grain refinement of the C45 steel was investigated. The ASR (accelerated carbide spheroidisation and refinement) process allows us to achieve a microstructure made of fine ferrite grains and globular carbides in seconds or minutes. This paper deals with the ASR process realization via the thermomechanical processing of controlled rolling. Hot rolling is a common part of structural steel processing. A conventional structure after the hot rolling of the $\mathrm{C} 45$ steel consists of lamellar pearlite and ferrite. During controlled rolling with a deformation at temperatures around critical temperature $A_{1}$, it is possible to achieve a microstructure of a fine ferritic matrix and globular carbides. The deformation causes a recrystallization of the ferritic matrix - a grain refinement. Furthermore, a high dislocation density during the deformation enhances the diffusion and promotes carbide spheroidisation. The aim of the experimental program was to achieve a microstructure of the C45 steel consisting of fine ferritic grains and homogeneously dispersed cementitic globular particles by processing bars in a laboratory rolling mill. The morphological changes of the cementite after the thermomechanical treatment in comparison with the conventional hot rolling were investigated as well as the ferritic grain refinement. An image analysis was performed to determine the spheroidisation level of the cementite (the aspect ratio of cementite particles) and the ferritic grain size. A proper examination of a cementite morphology can be carried out only by observing the entire cementite particle. A common metallographic analysis relies on a $2 \mathrm{D}$ section observation. Thus, deep etching and cementite extraction were performed to study the cementite-particle shape formed during the ASR process.

Keywords: accelerated spheroidisation, carbide morphology, rolling, C45 steel
\end{abstract}

Preiskovana je bila sferoidizacija perlita in zmanjšanje zrn v jeklu C45. Proces ASR (pospešena sferoidizacija perlita in rafinacija) omogoča $v$ nekaj sekundah ali minutah doseči mikrostrukturo iz drobnih feritnih zrn in globularnih karbidov. Ta članek predstavlja izvedbo ASR-procesa s termomehansko obdelavo pri kontroliranem valjanju. Vroče valjanje je znan postopek pri preoblikovanju jekla. Navadno je mikrostruktura po vročem valjanju jekla C45 iz lamelarnega perlita in ferita. Pri kontroliranem valjanju, $\mathrm{z}$ deformacijo pri temperaturah okrog kritične temperature $A_{1}$, je mogoče doseči mikrostrukturo iz drobnozrnate feritne osnove in globularnih karbidov. Deformacija povzroči rekristalizacijo feritne osnove in zmanjšanje velikosti zrn. Poleg tega velika gostota dislokacij med deformacijo pospešuje difuzijo in spodbuja sferoidizacijo karbidov. Namen programa preizkusov je bil doseči pri jeklu C45 mikrostrukturo iz drobnih feritnih zrn in homogeno razporejenimi globularnimi cementitnimi delci z valjanjem palic pri laboratorijskem valjanju jekla. Preiskovane so bile spremembe v morfologiji cementita po termomehanski obdelavi v primerjavi z navadnim vročim valjanjem, kot tudi udrobnjenje feritnih zrn. Stopnja sferoidizacije cementita (razmerje med dolžino in debelino cementitnih delcev) in velikosti feritnih zrn je bila izvršena $z$ analizo slik. Pravilen pregled morfologije cementita je lahko izveden samo z opazovanjem celotnega cementitnega delca. Navadne metalografske analize se opirajo na 2D-opazovanje prereza. Za študij oblike cementitnih delcev, ki nastajajo med ASR-procesom, je bilo zato izvršeno globoko jedkanje in ekstrakcija cementita.

Ključne besede: pospešena sferoidizacija, morfologija karbidov, valjanje, jeklo C45

\section{INTRODUCTION}

Carbide spheroidisation is an integral part of processing many types of steel, especially high-carbon steels. The ASR process (accelerated carbide spheroidisation and refinement) can also be used for mild-carbon steels as a way of strengthening them and enhancing their toughness.

To quantify carbide spheroidisation, an image analysis of the micrographs of a metallographic section is usually used. This 2D view of a steel structure cannot provide reliable information about the real 3D shape of cementite particles. A morphological development from carbide lamellae to globular particles includes the exi- stence of complicated carbide shapes which can only be determined with a $3 \mathrm{D}$ view.

A carbide morphology in different stages of spheroidisation is directly observable with SEMs of extracted carbides, 3D tomography using FIB $\mathrm{SEM}^{1}$ or TEM of extracted carbide particles. ${ }^{2}$

This article describes the cementite morphology in the C45 steel after the ASR process. The experimental steel was thermomechanically treated in order to achieve a different degree of cementite spheroidisation and ferritic grain size. The degree of carbide spheroidisation was determined with the conventional metallographic-section method. A direct observation of the cementite particles 
extracted from the ferritic matrix was performed to reveal the spheroidisation mechanism.

\section{EXPERIMENTAL WORK}

\subsection{Material}

The experimental program was performed using structural carbon steel C45 with the chemical composition shown in Table 1. The initial state was a hot-rolled bar $50 \mathrm{~mm}$ in diameter. The hardness of the as-received material was $180 \mathrm{HV}_{30}$. The initial dimensions of the specimens for the thermomechanical treatment were a length of $330 \mathrm{~mm}$, a width of $50 \mathrm{~mm}$ and a height of 30 $\mathrm{mm}$.

Table 1: Chemical composition of C45 steel (w/\%)

Tabela 1: Kemijska sestava jekla C45 (w/\%)

\begin{tabular}{|c|c|c|c|c|c|c|c|c|c|}
\hline $\mathrm{C}$ & $\mathrm{Si}$ & $\mathrm{Mn}$ & $\mathrm{S}$ & $\mathrm{P}$ & $\mathrm{Cr}$ & $\mathrm{Ni}$ & $\mathrm{Cu}$ & $\mathrm{Mo}$ & $\mathrm{W}$ \\
\hline 0.42 & 0.24 & 0.69 & 0.019 & 0.016 & 0.12 & 0.16 & 0.12 & 0.02 & 0.01 \\
\hline
\end{tabular}

\subsection{Thermomechanical treatment}

The thermomechanical treatment was carried out on a laboratory rolling mill at a duo configuration. The roll's diameter was $550 \mathrm{~mm}$, the maximum width of the sheet was $400 \mathrm{~mm}$ and the range of the sheet thickness was from $5 \mathrm{~mm}$ to $100 \mathrm{~mm}$. The maximum rolling speed was $1.5 \mathrm{~m} / \mathrm{s}$. This speed was also chosen for the experiment. The rolling mill was equipped with pyrometers on both sides of the mills monitoring the specimen temperature. The temperature was measured in the specimen centre.

Regimes of the thermomechanical processing were chosen to reveal the influence of the deformation temperature and intensity upon the final ferritic grain size and carbide morphology.

The regimes for the accelerated pearlite spheroidisation consisted of a deformation at temperature $T_{\mathrm{D} 1}=850$ ${ }^{\circ} \mathrm{C}$ (a single thickness reduction from $30 \mathrm{~mm}$ to $20 \mathrm{~mm}$ ) and air cooling of the samples to $675^{\circ} \mathrm{C}$. Then the temperature rose to about $683{ }^{\circ} \mathrm{C}$ due to the latent heat of the pearlitic transformation and decreased again. The second deformation was introduced when the temperature of the samples decreased again to $T_{\mathrm{D} 2}=675{ }^{\circ} \mathrm{C}$ after the pearlitic transformation, as seen in Figure 1. The second deformation consisted of a single reduction (from the

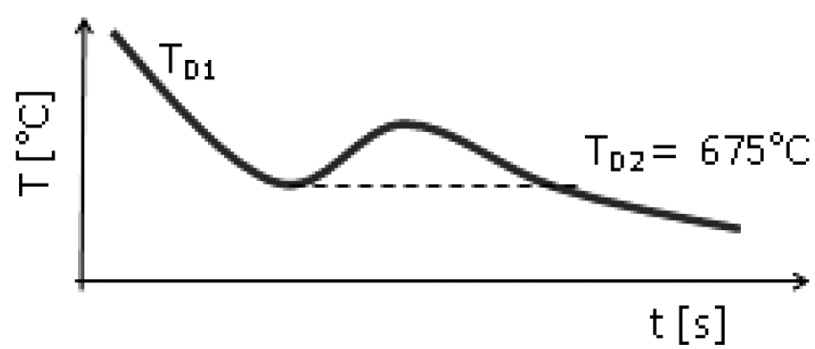

Figure 1: Transformation stages, at which deformation was applied Slika 1: Transformacijske faze, pri katerih je bila izvršena deformacija thickness of $20 \mathrm{~mm}$ to $12 \mathrm{~mm}$ ) or two reductions $(20 \mathrm{~mm}$ $\rightarrow 12 \mathrm{~mm}$ and $12 \mathrm{~mm} \rightarrow 7 \mathrm{~mm}$ ) introduced in $10 \mathrm{~s}$.

The regimes for a combination of carbide spheroidisation and ferritic grain refinement were also performed. The samples austenitized at $850{ }^{\circ} \mathrm{C}$ were cooled on air to $710{ }^{\circ} \mathrm{C}$, deformed (a single thickness reduction from 30 $\mathrm{mm}$ to $20 \mathrm{~mm}$ ) and cooled down. Samples 2, 3, 5 and 6 were deformed at a temperature of $675^{\circ} \mathrm{C}$ after the pearlitic transformation with one or two reductions.

\subsection{Carbide-morphology examination}

The metallographic section from each sample was prepared and etched in the Nital etchant. The degree of carbide spheroidisation was quantified with an image analysis of 10 micrographs at a 5000-times SEM magnification. The Nis Element software ${ }^{3}$ was used for the image analysis. Each image was turned into a binary image and the carbides were measured. The area, length and width of each carbide particle were measured automatically. The aspect ratio (AR) was computed as the particle length divided by its width. The measured carbides were subsequently divided into categories according to their ARs. The cementite percentage for each category was computed as the area percentage of carbides in each category to the overall cementite area.

The real 3D morphology of cementite particles was revealed by deep etching the samples in Nital for $60 \mathrm{~min}$. Carbide particles were extracted with ultrasound in an alcohol bath, spread onto a copper pad and observed with SEM.

\section{RESULTS AND DISCUSSION}

\subsection{Metallographic observation}

\subsubsection{Carbide distribution and the ferritic grain size}

The microstructures of samples 1 and 4 (Table 2) were ferrite-pearlite with lamellar pearlite. Both ferritic and pearlitic grains were mostly polygonal and equiaxed. The ferritic grains in sample 1 exhibited a uniform size between $10 \mu \mathrm{m}$ and $20 \mu \mathrm{m}$. Sample 4 exhibited two types of ferritic grains. Most of the ferrite was present as equiaxed grains with a diameter from $20 \mu \mathrm{m}$ to $30 \mu \mathrm{m}$. About $15 \%$ of ferrite was in the form of fine equiaxed grains with a diameter from $2 \mu \mathrm{m}$ to $4 \mu \mathrm{m}$. These finely grained areas were about $20 \mu \mathrm{m}$ large, while the ferritic

Table 2: List of schedules

Tabela 2: Seznam opravljenih deformacij

\begin{tabular}{|c|c|c|c|}
\hline Regime & Preheating & First deformation & $\begin{array}{c}\text { Second } \\
\text { deformation }\end{array}$ \\
\hline 1 & \multirow{6}{*}{$\begin{array}{l}850{ }^{\circ} \mathrm{C} \\
60 \mathrm{~min}\end{array}$} & $850^{\circ} \mathrm{C} ; \varphi=0.4$ & - \\
\hline 2 & & $850^{\circ} \mathrm{C} ; \varphi=0.4$ & $675^{\circ} \mathrm{C} ; \varphi=0.5$ \\
\hline 3 & & $850{ }^{\circ} \mathrm{C} ; \varphi=0.4$ & $675^{\circ} \mathrm{C} ; \varphi=1$ \\
\hline 4 & & $710^{\circ} \mathrm{C} ; \varphi=0.4$ & - \\
\hline 5 & & $710^{\circ} \mathrm{C} ; \varphi=0.4$ & $675^{\circ} \mathrm{C} ; \varphi=0.5$ \\
\hline 6 & & $710^{\circ} \mathrm{C} ; \varphi=0.4$ & $675^{\circ} \mathrm{C} ; \varphi=1$ \\
\hline
\end{tabular}




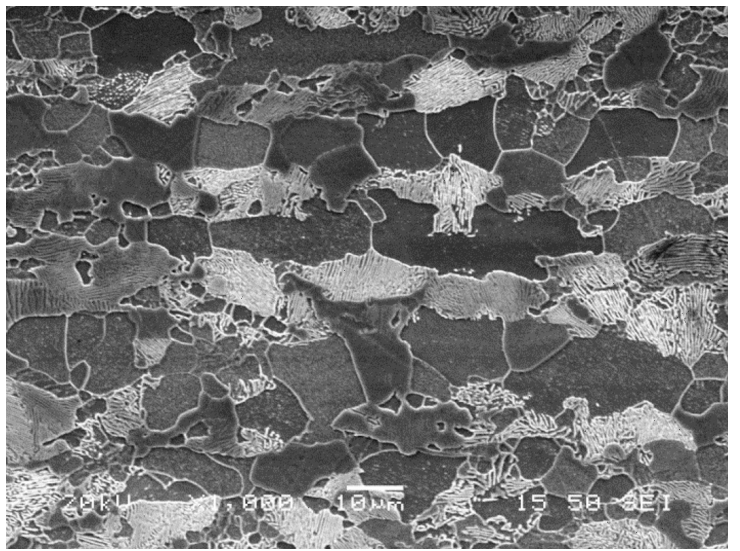

Figure 2: Regime 4: ferrite pearlite structure with fine-grained areas Slika 2: Režim 4: feritno-perlitna struktura s področji drobnozrnatosti

and pearlitic grains of the same size were mixed together (Figure 2). It is assumed that the deformation-induced ferritic transformation took place in these regions during the rolling at $710{ }^{\circ} \mathrm{C}$.

The elongation of the structure was caused by further reduction(s) at the temperature of $675^{\circ} \mathrm{C}$. The cementite was still located in the elongated pearlitic region; the redistribution of the cementite into the originally ferritic areas was not observed. The elongated ferritic grains exhibited a deformation substructure (Figure 3).

\subsubsection{Carbide spheroidisation}

The deformation introduced at the temperature of 675 ${ }^{\circ} \mathrm{C}$ after the pearlitic transformation caused a rapid fragmentation of the pearlitic lamellae and a cementite spheroidisation. Samples 2 and 5 exhibited the same cementite morphology and so did samples 3 and 6 . Thus, the temperature of the first deformation $\left(850{ }^{\circ} \mathrm{C}\right.$ or $\left.710{ }^{\circ} \mathrm{C}\right)$ did not affect the cementite morphology.

Pearlitic lamellae of samples 2 and 5 were fragmented; the image analysis of the metallographic-section micrographs showed a significant amount of cementite

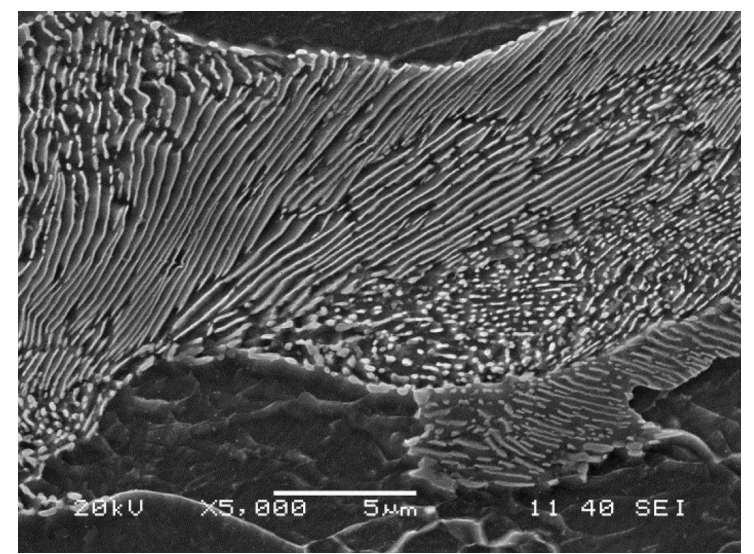

Figure 3: Regime 2: metallographic section shows partially fragmented and spheroidised cementite lamellae

Slika 3: Režim 2: metalografski prerez prikazuje delno fragmentirane in sferoidizirane cementitne lamele with a fully spheroidised shape (Table 3). However, deep etching and cementite extraction revealed cementite lamellae of a complicated shape with many holes and branches and almost no isolated cementite particles.

Table 3: Aspect ratio of cementite particles in samples 2, 3, 5 and 6 deformed in the ferritic-pearlitic state

Tabela 3: Razmerje med dolžino in debelino cementitnih delcev v vzorcih 2, 3, 5 in 6, deformiranih v feritno-perlitnem stanju

\begin{tabular}{|c|c|c|c|c|}
\hline \multirow{2}{*}{$\begin{array}{c}\text { Aspect } \\
\text { ratio }\end{array}$} & \multicolumn{4}{|c|}{ Fraction (\%) } \\
\cline { 2 - 5 } & Reg. 2 & Reg. 3 & Reg. 5 & Reg. 6 \\
\hline $1-3$ & 20.8 & 19.8 & 24.7 & 24.8 \\
\hline $3-6$ & 15.9 & 14.9 & 18.3 & 19.0 \\
\hline $6-12$ & 20.1 & 19.5 & 22.6 & 23.1 \\
\hline$>12$ & 43.2 & 45.8 & 343 & 33.1 \\
\hline
\end{tabular}

A deformation with intensity $\varphi=0.5$ at the temperature of $675{ }^{\circ} \mathrm{C}$ (samples 2 and 5) did not cause the main fragmentation of the cementite lamellae into smaller pieces but rather into branches and "lace-like" shapes (Figure 4). The cementite lamellae were transformed into a mixture of rods/branches connected together, still following the original shape and size of the cementite lamella. The cementite rods/branches were mostly segmented and were observed as chains of intersecting globular particles. The segments usually had a diameter of $0.1 \mu \mathrm{m}$ to $0.3 \mu \mathrm{m}$.

A deformation with intensity $\varphi=1$ at the temperature of $675^{\circ} \mathrm{C}$ (samples 3 and 6) caused a pearlitic-structure fragmentation and spheroidisation according to the conventional metallography as well as deep etching and carbide extraction. The cementite lamellae were fragmented into objects, usually of up to $3 \mu \mathrm{m}$ in the longest direction. These fragments were segmented into globular connected particles. Isolated globular cementitic particles in the same size range were also observed (Figure 5).

One third of the pearlite in the structures of samples 3 and 6 (Table 2) remained non-fragmented and la-

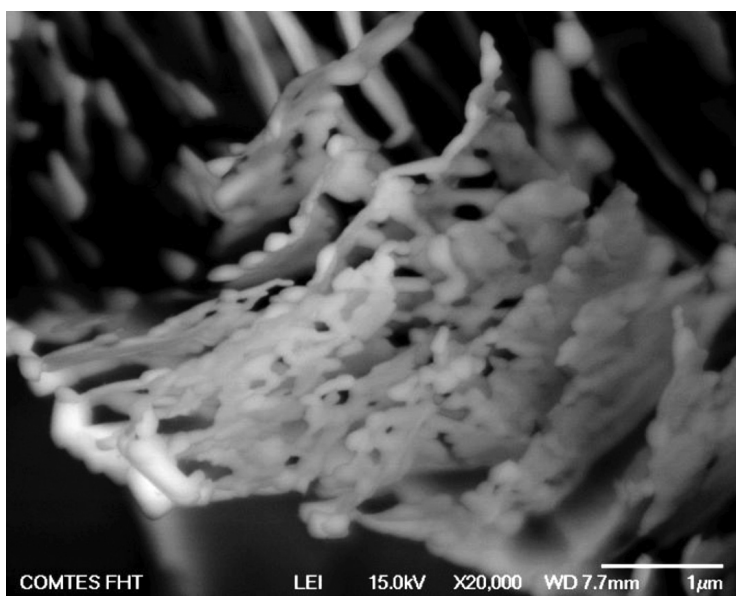

Figure 4: Regime 2: deep etching revealed branched remnants of original pearlite lamellae and almost no globular particles

Slika 4: Režim 2: globoko jedkanje odkrije razvejane ostanke originalnih perlitnih lamel in skoraj nič globularnih delcev 


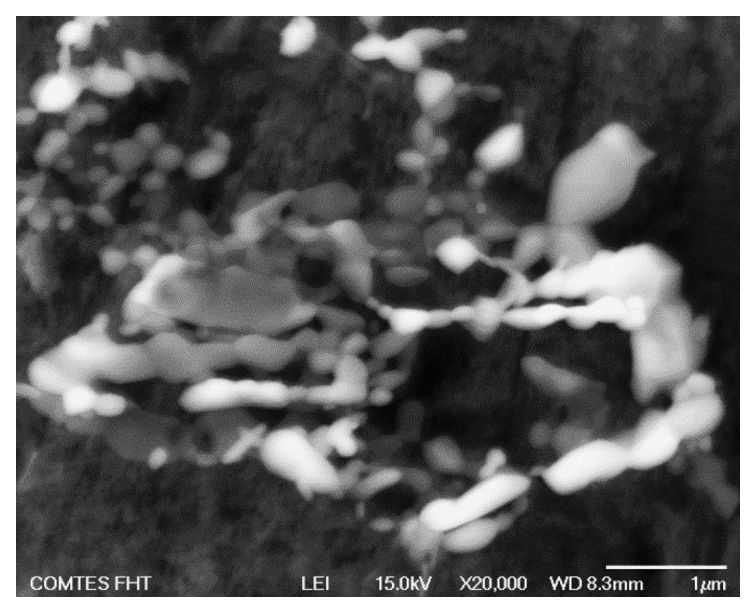

Figure 5: Regime 3: extracted cementite; lamella fragments and globular particles

Slika 5: Režim 3: izolirani cementit; delci lamel in globularni delci

mellar. The pure lamellar form differs significantly from the predominantly observed highly fragmented or spheroidised morphology. A possible explanation is that the lamellar pearlite could have been formed after the last deformation. The temperature of $675^{\circ} \mathrm{C}$ after the temperature peak during the pearlitic transformation was probably not sufficiently low to ensure a complete austenite decomposition.

\section{CONCLUSION}

The thermomechanical treatment of the C45 steel showed changes in the ferritic grain size and cementite morphology according to the deformation temperature and intensity.

The deformation prior to the pearlitic transformation had a significant influence on the ferritic grain size. A uniform structure with a ferritic grain size of about 15 $\mu \mathrm{m}$ was obtained with the conventional hot rolling at 850 ${ }^{\circ} \mathrm{C}$. The deformation during the air cooling at a temperature of $710{ }^{\circ} \mathrm{C}$ caused a formation of fine ferritic grains of up to $3 \mu \mathrm{m}$ in diameter; however, most of the ferrite was formed before in the form of ten-times-larger grains.

The pearlitic transformation of austenite resulted in a lamellar cementite morphology at both temperatures of the austenite deformation $\left(850\right.$ and $710{ }^{\circ} \mathrm{C}-$ the undercooled austenite).

The cementite morphology was influenced by the deformation of pearlite. The deformation at $675{ }^{\circ} \mathrm{C}$ after the pearlitic transformation caused a fragmentation of the cementite lamellae. The deformation with intensity $\varphi$ $=0.5$ induced holes and branching of the original cementite lamellae. The deformation with intensity $\varphi=1$ caused a cementite-lamella fragmentation. Fragments with the maximum size of $3 \mu \mathrm{m}$ were observed in the structure and a significant amount of globular cementite particles, mostly with a diameter of $0.1 \mu \mathrm{m}$ to $0.3 \mu \mathrm{m}$, were also formed.

A more homogeneous dispersion of cementitic globular carbides in the ferritic matrix can be ensured with the formation of fine proeutectoid ferrite. Further experiments will be focused on the ferrite grain refinement with a deformation above temperature $A \mathrm{c} 1$.

\section{Acknowledgment}

The results presented in this paper were obtained under project West-Bohemian Centre of Materials and Metallurgy CZ.1.05/2.1.00/03.0077, co-funded by the European Regional Development Fund.

\section{REFERENCES}

${ }^{1}$ Y. Adachi, K. Nakajima, Y. Sugimoto, Quantitative three-dimensional characterization of pearlite spheroidization, Acta Materialia, 58 (2010), 4849-4858, doi:10.1016/j.actamat.2010.05.023

${ }^{2}$ Y. L. Tian, R. W. Kraft, Mechanisms of Pearlite Spheroidisation, Metallurgical Transactions A, 18 (1987) 8, 1403-1414, doi:10.1007/ BF02646654

${ }^{3}$ Nis-Element software, internet site of the producer: http://www.niselements.cz/en/front-page 